\title{
ФУНКЦІОНУВАННЯ ФУНДАМЕНТАЛЬНОЇ БІБЛІОТЕКИ КИЇВСЬКОЇ ДУХОВНОЇ СЕМІНАРІЇ У ДРУГІЙ ПОЛОВИНІ ХІХ - НА ПОЧАТКУ ХХ ст.
}

\begin{abstract}
Анотація: Досліджено важливу складову історії Київської духовної семінарії - функціонування ї̈ головної бібліотеки. З'ясовано, що попри науковий характер література книгосховища була вагомою частиною навчальної інфраструктури. Охарактеризовано особливості впорядкування літературних фондів в останній чверті ХІХ ст. Детально проаналізовано те, як змінювався склад і наповнення фундаментальної бібліотеки протягом другої половини XIX - початку XX ст. Виявлено, що якщо у 1880-х рр. в даному книгосховищі знаходилося 6 тис. книг у 12 тис. томах, то напередодні Першої світової війни тут вже було майже 12 тис. книг у 20 тис. томах. Звернено увагу на серйозну цензуру й обмеження книжкового обігу відомствами Св. Синоду. Показано особливості закупівлі та придбання літератури до бібліотеки.
\end{abstract}

Ключові слова: православна церква, середня духовна освіта, духовні семінарії, Київська духовна семінарія, бібліотека, книгосховище, література

Одним 3 найавторитетніших духовних навчальних закладів на українських землях Російської імперії протягом усього XIX - початку XX ст. залишалася Київська духовна семінарія. Важливою невід'ємною складовою ії інфраструктури була фундаментальна (тобто основна, головна) бібліотека. Книгосховище цього освітнього закладу, як один 3 найважливіших засобів його навчального процесу, заслуговує на окрему особливу увагу.

Актуальність обраної теми зумовлюється складнощами, що пов'язані з проблемами матеріального забезпечення сучасних навчально-виховних установ. У багатьох українських школах навіть у наш час відчувається нестача навчальної літератури та підручників, історичних і географічних карт, приладів до хімічних і фізичних кабінетів, методичних матеріалів для вчителів і т. п. Хронічними є труднощі фінансового характеру.

Публікація дозволяє визначити роль фундаментальної бібліотеки в історії Київської духовної семінарії протягом другої половини XIX - початку XX ст. Метою цієї наукової розвідки є спроба дослідити діяльність, наповнення, склад і вміст головної бібліотеки Київської духовної семінарії (далі - КДС). Хронологічними межами цієї публікації є 1867 р. i 1919 р. - від моменту прийняття нового статуту духовних семінарій до закриття навчального закладу, в якому розміщувалося книгосховище.

Обрана тема забезпечена хорошою джерельною базою, основна маса якої зосереджена у Центральному державному історичному архіві України м. Києва. Зокрема, надзвичайно вагомим є фонд № 712 «Київська духовна семінарія». Але попри це, подібні питання лишилися без уваги сучасних науковців. Загальне грунтовне дослідження історії

\footnotetext{
“Бідун Юрій Володимирович - аспірант історичного факультету Національного педагогічного університету імені М.П. Драгоманова; ORCID: https://orcid.org/0000-0002-9155-8004; e-mail: bidun1992@gmail.com
} 
КДС з 1817 по 1867 рр. провів С. Ільчишин ${ }^{1}$. Також вищу, середню та нижчу духовну освіту на українських землях активно вивчали такі вчені, як В. Борисенко, В. Бурега, С. Візер, Л. Іванова, Т. Ковальчук, В. Перерва, В. Рожко, А. Сергієнко, Г. Степаненко, О. Федорчук, Н. Ципляк, Н. Шип та ін.

Загальні найпростіші норми діяльності фундаментальної бібліотеки КДС у другій половині XIX - на початку XX ст. прописували семінарські статути 1867 і 1884 рр. При цьому, залишалися дійсними деякі положення статуту 1814 р. §§ 142-144 і семінарського статуту 1867 і §§ 134-136 статуту 1884 рр., які не лише законодавчо закріплювали існування при кожній семінарії бібліотек, а й частково регулювали їхню діяльність.

У журналі педагогічного зібрання Київської духовної семінарії від 12 грудня 1868 р. наведено зразок правил і порядку збереження та видачі книг із бібліотеки. Цей проект складався виконуючим обов'язки інспектора Павлом Розановим і колишнім бібліотекарем Харисимом Ордою ще у жовтні 1868 p. ${ }^{2}$ Згодом він був затверджений. Ці правила майже повністю регулювали функціонування бібліотеки Київської духовної семінарії та складалися з трьох частин.

Перша - стосувалася прийому книг до бібліотеки та їх внутрішнього збереження. У ній, зокрема, вказувалося, що придбання книг і журналів - обов'язок бібліотекаря. Він складає проект кошторису на закупівлю нових книг, але гроші ці видаються йому лише при ухвалі педагогічного зібрання правління семінарії. Книги та журнали виписуються на ім'я семінарської бібліотеки і при отриманні вносяться в особливу книгу. Ї̈̈ повинен був перевіряти інспектор, у чиї обов'язки також входило звіряння рахунків 3 цього журналу 3 квитанціями книжкових крамниць. Книги видавалися у палітурці, для чого у семінарії знаходився постійний палітурник. Придбана література повинна були вноситися в каталоги. I щороку бібліотекар подавав звіт про виписані книги до правління семінарії.

Друга частина правил стосувалася власне користувачів бібліотеки, зокрема учнів, i регулювала порядок видачі книг. Тут вказувалося, що наставники отримують книги під власноручну розписку в спеціальному журналі. Казеннокоштні учні на початку кожного року отримують підручники. Одержання вони засвідчували власноручною розпискою у спеціально призначеному для цього журналі. Учні, що позбавлялися казенного утримання, повинні були повернути книги в бібліотеку. Зазначалося, що своєкоштні вихованці могли отримувати книги з фундаментальної семінарської бібліотеки на рівних правах 3 казеннокоштними. Але для цього від них вимагалося надати бібліотекарю записку від учителя. Стародавні, рідкісні книги, а також рукописи вихованцям не видавалися. Література видавалася двічі на тиждень у призначені самим же бібліотекарем дні. Учню, що мав записку про бажання отримати певну книгу, вона видавалася у наступний день видачі. Одноразово користувачі бібліотеки отримували не більше двох книг на особу. Термін утримання учнем виданої літератури - п'ять-сім днів.

У третій частині зазначалося, що на учнів покладалася відповідальність за цілісність бібліотечних книг. Різні «приписки, помарки, вирізки і т.п.» в бібліотечних книгах

\footnotetext{
${ }^{1}$ Ільчишин С.В. Історія Київської духовної семінарії в 1817-1867 роках: дис.... канд. богослов’я / Українська Православна Церква, Київська Духовна Академія, Свято-Успенська Києво-Печерська Лавра. Київ, 2018. 305 с.

${ }^{2}$ Центральний державний історичний архів України, м. Київ (далі - ЦДІАУ, м. Київ). Ф. 712. Оп. 3: 1868. Спр. 1: Журналы педагогического собрания. Арк. 125-127.
} 
позбавляли винного права на подальше отримання книг. За це ж учень повинен був відшкодовувати певну грошову суму. Якщо користувач пошкодив палітурку, вирвав статтю 3 книги (або хоча б один її листок), чи просто втратив книгу, то він повинен був оплатити вартість цілої книги. Вихованець, що втратив стопку журналу взамін виписує його повне річне видання ${ }^{3}$.

У правилах про дисциплінарні стягнення з учнів КДС теж зазначалися обмеження при бібліотечній роботі семінаристів ${ }^{4}$. Вказувалося, що читанням книг учні повинні займатися відповідно до § 135 семінарського статуту, а саме - під наглядом своїх наставників. Отримувати книги з інших бібліотек поза семінарією дозволялося лише з відома інспектора. Учень повинен був письмово подати інспектору заяву, в якій обов'язково зазначалися автор і назва книги. Подання прохання про це відбувалося через чергового старшого і відповідь інспектора на цю заяву теж можна було отримати через нього 5 .

Грошові суми, на які утримувалася фундаментальна бібліотека, входили у семінарський річний кошторис й обраховувалися як окрема стаття у § Господарські витрати. У 1867-1871 рр. витрати на утримання бібліотеки були в розмірі 137 руб. ${ }^{6}$ У подальші роки витрати стрімко збілышувалися. Пов'язано це було з наповненням фізичного кабінету; витрати на фізико-математичний кабінет і на бібліотеку обраховувались по одній і тій же статті кошторису. У першій половині 1880-х рр. у кошторисах витрати на фундаментальну бібліотеку складали по 400 руб. на рік․ у 1884 р. витрати на закупку та переплетення книг, а також на приладдя до фізичного кабінету досягли 511 руб. 2 коп. ${ }^{8}$ Проте вже 3 другої половини 1880-х рр., на витрати, що пов'язані з фундаментальною бібліотекою, було виділено 325 руб. ${ }^{9}$ I надалі ця сума у річних кошторисних книгах залишатиметься ста́лою всі подальші роки існування КДС ${ }^{10}$. Щоправда, фактичні, себто реальні річні витрати на утримання фундаментальної бібліотеки та фізичного кабінету часто були значно меншими від зазначеної суми. Це сприяло накопиченню надлишку коштів на утримання та поповнення фондів бібліотеки.

На 1875 р. в правлінні семінарії вже було ухвалено рішення, що придбання книг для КДС необхідно здійснювати за такими принципами: а) щоб сума, яка вимагалася для закупки книг не перевищувала грошових засобів, якими оперують фундаментальна й уч-

\footnotetext{
${ }^{3}$ ЦДІАУ, м. Київ. Ф. 712. Оп. 3: 1868. Спр. 38: 0 составлении инструкции для инспектора Семинарии и правил о порядке хранений и выдачи книг из библиотеки. Арк. 1-6.

${ }^{4}$ ЦДІАУ, м. Київ. Ф. 712. Оп. 3: 1868. Спр.114: Правила о дисциплинарных взысканиях с учеников. 25 арк.

${ }^{5}$ Ibid. Арк. 6.

${ }^{6}$ ЦДІАУ, м. Київ. Ф. 712. Оп. 3: 1867. Спр.142: Смъта доходовъ по Киевской епархіи на содержаніе ДуховноУчебныхъ заведеній, за исключеніемъ Кіевской Академіи на 1867 годъ. Арк. 11-13; Оп. 3: 1871. Спр. 1: Училищные журналы. Арк. 13-15.

${ }^{7}$ ЦДІАУ, м. Київ. Ф. 712. Оп. 3: 1880. Спр. 69: Отчетъ о приходъ, расходъ и остаткъ суммъ по содержанію Кіевской духовной Семинаріи. За 1880 годъ. 157 арк.

${ }^{8}$ ЦДІАУ, м. Київ. Ф. 712. Оп. 3: 1884. Спр. 59: Отчеть о приходъ, расходъ и остаткъ суммъ по содержанію Кіевской Духовной Семинаріи. За 1884 годъ. Арк. 125-132.

${ }^{9}$ ЦДІАУ, м. Київ. Ф. 712. Оп. 3: 1887. Спр. 23: Смета доходов по Семинарии и училищ (О составленіи смЂты на 1888 г.). 187 арк.

${ }^{10}$ ЦДІАУ, м. Київ. Ф. 712. Оп. 3: 1897. Спр. 24: Отчетъ о приходъ, расходъ и остаткъ суммъ по содержанію Кіевской духовной Семинаріи въ 1896 г. 124 арк.; Оп. 4: 1908. Спр. 452: Экономическій отчетъ по Кіевской духовной семинаріи за 1908 годъ. 221 арк.
} 
нівська бібліотека; б) щоб наявні гроші були розподілені якомога рівніше на кожну 3 наук, яка викладається ${ }^{11}$.

Обмін навчальною та науковою літературою здійснювався на комерційній основі. Тобто, вона купувалася і продавалася. Видавництва рекламували свою друковану продукцію, розсилали брошури, різні оголошення про можливість придбати в них той чи інший екземпляр за запропоновану ціну. Після ознайомлення з рекламними брошурками духовні навчальні заклади вирішували, варто чи ні придбати пропоновану продукцію. Зазвичай, про отримання чи покупку книг звітувалися перед синодальним керівництвом ${ }^{12}$.

При цьому схвалення великих за обсягом закупівель відомствами Св. Синоду було обов'язковим. Друкувати книги у власних друкарнях теж можна було лише 3 дозволу Св. Синоду. На деякі підручники вищі церковні відомства видавали рекомендації, а деякі - наполегливо вимагали придбати. Часто це було пов'язано з тим, що видання виходили в кількості, яка точно розраховувалася для всіх семінарій та училищ. У КДС таких інформаційних і рекомендаційних листів з відомств Св. Синоду надходило надміру багато.

У місцевих продавців книги закуповували у великих кількостях. Наприклад, книготорговець Літов у 1874 р. доставив до фундаментальної бібліотеки 72 найменування книг на релігійно-педагогічну тематику на суму 161 руб 53 коп. (це з 5\% по́ступкою в ціні). Книготорговці Гінтер і Малецький продали семінарії лише дві книги іноземною мовою, але їх вартість становила 34 руб. 30 коп. 3 цього випливає, що вартість іноземних видань була значно вищою за ціну вітчизняних книг. Наприклад, другий том «Підручника з історії церкви» Гізелера (Lehrbuch der Kirchengeschichte von Gieseler) коштував аж 31 руб. 90 коп. I це при тому, що більшість книг з вітчизняних видавництв, які надходили до КДС, коштували від 2 до 5 руб. ${ }^{13}$

Одним 3 найважливіших постачальників релігійної та навчальної літератури для КДС була Московська Синодальна Типографія. В одному з інформаційних листів, що надійшли в КДС у 1895 р. зазначалося, що з цього видавництва можна замовити книги на будь-яку тематику ${ }^{14}$. Такі оголошення часто надходили до канцелярії КДС. Варте уваги й те, що у Московській Синодальній Типографії друкувалися майже всі укази Св. Синоду, що розсилалися семінаріям. Середні духовні навчально-виховні заклади отримували такого роду документи щомісячно, а інколи й частіше.

Як вже вказувалося вище, бібліотека поповнювалася такою кількістю літератури, яку була змога закупити на спеціально відведені для цього суми в кошторисі. Обсяг щорічно придбаних книг прямо залежав і від ціни на кожну окремо взяту одиницю літератури. Тому, в другій половині ХІХ ст. її кількість дуже сильно коливалася.

У 1869 р. $з$ однієї з доповідей інспектора випливало, що для семінарської бібліотеки

\footnotetext{
${ }^{11}$ ЦДІАУ, м. Київ. Ф. 712. Оп. 3: 1875. Спр. 51: 0 выписке книг и журналов и покупке для фундаментальной библиотеки (отчет о состоянии библиотеки). Арк. 21.

${ }^{12}$ ЦДІАУ, м. Київ. Ф. 712. Оп. 3: 1867. Спр. 82: О выписке книг и периодическых изданий для библиотеки Семинарии (за 1867). 161 арк.

${ }^{13}$ ЦДІАУ, м. Київ. Ф. 712. Оп.3: 1874. Спр. 35: 0 выписке и покупке книг и журналов для фундаментальной библиотеки семинарии (Отчет о книгах безмездно раздачи ученикам, ведомость о продаже книг). Арк. 61.

${ }^{14}$ ЦДІАУ, м. Київ. Ф. 712. Оп.3: 1895. Спр. 7: 0 поступленіи книгъ в фундаментальную и ученическую библіотеку. 37 арк.
} 
необхідно було закупити періодичних видань на суму 92 руб. 20 коп. ${ }^{15}$ На педагогічних зборах 5 березня 1880 р. правлінню семінарії пропонувалося виписати для фундаментальної, учнівської бібліотек і недільної школи близько 250 екземплярів, з яких 153 книги направлялося в основну бібліотеку ${ }^{16}$. Але, фактично, у 1880 р. для фундаментальної бібліотеки було куплено лише 123 екземпляри книг ${ }^{17}$. Протягом 1882 р. фундаментальна бібліотека отримала 107 назв книг у 230 томах, з яких 16 назв періодичних видань у 62 томах ${ }^{18}$. у 1883 р. для неї купили 165 екземплярів книг і 6 періодичних видань, а також 100 книг Саратовського духовно-просвітницького союзу («Общеупотребительныя молитвы и пъснопЊнія православной церкви») на загальну суму 450 руб. ${ }^{19}$ У 1885 р. планувалося виписати 80 екземплярів книг в основну бібліотеку ${ }^{20} .7$ квітня 1888 р. правління семінарії схвалило список книг для придбання в книгосховища семінарії. Планувалося закупити 106 назв для основної та 80 назв літератури для учнівської бібліотек ${ }^{21} .11$ березня 1893 р. правління схвалило закупку 114 книг для фундаментальної та 31 книги для учнівської книгарень семінарії ${ }^{22} .8$ березня 1894 р. планувалося закупити 105 назв книг у фундаментальну та 45 у учнівську бібліотеки ${ }^{23}$.

Правління семінарії зобов'язувало викладачів попередньо записувати назви книг, яких їм не вистачало, перед тим, як їх придбати для занять 3 семінаристами. Для таких записів заводилися особливі журнали ${ }^{24}$.

Інколи до бібліотеки надходили неординарні, досить цікаві видання, що чудово відомі сучасним науковцям і дослідникам. У 1874 р., окрім іншої літератури, для учнів КДС виписався один екземпляр другого видання Остромирового Євангелія. Метою цього було вдосконалити вміння вихованців читати церковнослов'янською мовою ${ }^{25}$. у 1890 р. 3 управління генерал-губернатора в КДС було надіслано другий том п'ятої частини «Архіву Південно-Західної Росії» в двох екземплярах. Вони містили переписи єврейського населення на українських землях у XVIII ст. ${ }^{26}$

\footnotetext{
${ }^{15}$ ЦДІАУ, м. Київ. Ф. 712. Оп. 3: 1869. Спр. 86: О выписке книгъ и періодическихъ изданій для семинарской библіотеки и училищ ей подведомыхъ. Арк. 1.

${ }^{16}$ ЦДІАУ, м. Київ. Ф. 712. Оп. 3: 1880. Спр. 51: 0 выписке книг и журналов для фундаментальной библиотеки и приобритении для физического кабинета приборов и разных принадлежностей. Арк. 16.

${ }^{17}$ ЦДІАУ, м. Київ. Ф. 712. Оп. 3: 1880. Спр. 69: Отчеть о приходъ, расходъ и остаткъ суммъ по содержанію Кіевской духовной Семинаріи. За 1880 годъ. 157 арк.

${ }^{18}$ ЦДІАУ, м. Київ. Ф. 712. Оп. 3: 1883. Спр. 35: Дьло по библіотекъ. Арк. 50.

${ }^{19}$ ЦДІАУ, м. Київ. Ф. 712. Оп. 3: 1883. Спр. 64: Отчетъ о приходъ, расходъ и остаткъ суммъ по содержанію Кіевской духовной Семинаріи за 1883 годъ. Арк. 117-118.

${ }^{20}$ ЦДІАУ, м. Київ. Ф. 712. Оп. 3: 1885. Спр. 14: О состоянии библиотеки фундаментальной и ученической, физического кабинета и о поступлении книг в библиотеку. Арк. 41-44.

${ }^{21}$ ЦДІАУ, м. Київ. Ф. 712. Оп.3: 1888. Спр. 18: О поступлении книг в фундаментальную библиотеку и о состоянии ея. 69 арк.

${ }^{22}$ ЦДІАУ, м. Київ. Ф. 712. Оп. 3: 1893. Спр. 8: 0 поступлении и выписке книг в фундаментальную и ученическую библиотеку. Арк. 15.

${ }^{23}$ ЦДІАУ, м. Київ. Ф. 712. Оп. 3: 1894. Спр. 8: 0 поступлении и выписке книг в фундаментальную библиотеку. Арк. 31-37.

${ }^{24}$ Ibid. Арк. 1.

${ }^{25}$ ЦДІАУ, м. Київ. Ф.712. Оп. 3: 1874. Спр. 35: 0 выписке и покупке книг и журналов для фундаментальной библиотеки семинарии (Отчет о книгах безмездно раздачи ученикам, ведомость о продаже книг). Арк.91-93. ${ }^{26}$ ЦДІАУ, м. Київ. Ф. 712. Оп. 3: 1890. Спр. 16: О поступлении книг в фундаментальную и ученическую библиотеку семинарии и духовных училищ. Отчет о состоянии библиотеки. Арк. 32.
} 
Наприкінці 1878 р. в основній бібліотеці КДС знаходилося 6517 книг в 11893 томах $^{27}$. У жовтні 1882 р. тут вже було 6452 назви книг у 12254 томах. Крім цього, в фундаментальній бібліотеці знаходилося 3925 навчальних посібників для безкоштовного використання казеннокоштними вихованцями. Також в ній знаходилися книги так званої «продажної бібліотеки», що на той момент були оціненими (за заниженими цінами, у порівнянні 3 книгопродавцями) на суму близько 500 руб. ${ }^{28}$

У листопаді 1881 р. фундаментальна бібліотека складалася з трьох відділень: навчальні посібники для викладачів і книги для читання; підручники для безкоштовного користування казеннокоштними учнями семінарії; навчальні книги і посібники для продажу своєкоштним вихованцям семінарії за нижчими цінами. Перше відділення включало в себе 6262 назви книг в 11692 томах, друге - 103 назви в 3906 екземплярах, а третє складалося з різних учбових книг, вартістю 583 руб. в грошовому еквіваленті ${ }^{29}$.

Станом на 30 червня 1883 р. у фундаментальній бібліотеці знаходилося 6543 назви книг у 12484 томах. Учням було безплатно роздано 180 книг, а в їх тимчасовому користуванні перебувало 2218 екземплярів ${ }^{30}$.

За наступні роки існування КДС кількість літератури тут подвоїлася.

Таблиця 1. Фонди фундаментальної бібліотеки станом на 1880 р.

\begin{tabular}{|c|c|c|}
\hline Назва фонду; рід, напрямок книг & Кількість назв & Кількість томів \\
\hline Стародавніми мовами (грецька, латина, іврит) & 1430 & 2307 \\
\hline Польською & 264 & 383 \\
\hline Німецькою & 260 & 435 \\
\hline Маловідомими мовами & 79 & 90 \\
\hline Російською & 3138 & 5419 \\
\hline \begin{tabular}{l|l} 
богослов'я \\
\end{tabular} & 788 & 1312 \\
\hline філософія & 286 & 477 \\
\hline словесність & 427 & 735 \\
\hline математика & 90 & 155 \\
\hline історія & 951 & 1809 \\
\hline мовознавство & 136 & 230 \\
\hline ті, що не належать до дух. освіти & 461 & 701 \\
\hline Рукописів & 133 & 135 \\
\hline Посібники історичні та географічні & \multicolumn{2}{|c|}{107 назв, 9 карт, 4 жетони } \\
\hline Бібліотека митрополита Філарета & 652 & 1007 \\
\hline Періодичні видання & 22 & 1401 \\
\hline
\end{tabular}

У звіті про стан фундаментальної бібліотеки за 1913-1914 навч. рік вказувалося, що

\footnotetext{
${ }^{27}$ Кіевская епархия въ 1878 году (продолженіе) // Кіевскія епархіальныя въдомости (далі - КЕВ). 1879. № 5.

${ }^{28}$ ЦДІАУ, м. Київ. Ф. 712. Оп. 3: 1882. Спр. 65: Записка о состоянии Киевской духовной семинарии за 1881/1882 год. Арк. 6.

${ }^{29}$ Извлеченіе изъ отчета о состояніи Кіевской духовной Семинаріи въ 1880/1 учебномъ году // КЕВ. 1881. №46.

${ }^{30}$ ЦДІАУ, м. Київ. Ф. 712. Оп. 3: 1883. Спр. 35: Дьло по библіотекъ. Арк. 50.
} 
фундаментальна бібліотека складалася 3 двох частин. До першої входили учбові посібники для викладачів і книги для читання. Цей відділ складався з 11984 назв книг у 20253 томах. До другої частини належали і підручники для безкоштовного користування казеннокоштними учнями семінарії. Це - всього до 1300 екземплярів ${ }^{31}$.

Досить вичерпне уявлення про фонди фундаментальної бібліотеки ми маємо 3 документу 1880 p. $^{32}$ На його основі нами було складено таблицю «Фонди фундаментальної бібліотеки станом на 1880 р.», яка наочно демонструє деякі факти про основну бібліотеку КДС (див. табл. 1).

По-перше, маємо всі підстави вважати це книгосховище повністю науковорелігійним, оскільки абсолютна більшість книг за своїм змістом не була педагогічного напрямку. По-друге, співвідношення найменувань книг російською мовою до книг іноземними мовами - 3:2. I як для середнього духовного навчального закладу - це високий показник. При цьому варто мати на увазі, що вихованці духовних навчальних закладах починали глибоко освоювати іноземні мови лише в семінаріях. Училищні курси на це не розраховувалися. По-третє, серед всіх книг іноземною мовою бл. 70\%, якщо вести підрахунки за найменуваннями книг, або бл. $60 \%$, якщо рахувати по томах, займає література стародавніми мовами, грецькою, латиною та івритом (єврейською мовою). Варто звернути увагу й на те, що у бібліотеці числилося 135 томів рукописів. А це, як ніщо інше, підтверджує суто науковий характер фундаментальної бібліотеки. Бо ж рукописи (навіть молоді) можна вважати першоджерелами, а наука (навіть богословська), грунтується на опрацюванні першоджерел. По-трете, навіть 3 огляду на тогочасні ринкові ціни, книги іноземними мовами купувалися і продавалися в рази дорожче, ніж російською. А це автоматично в рази піднімало фінансову вартість фондів фундаментальної бібліотеки, у порівнянні з усіма іншими подібними книгосховищами. Таким чином, книги, які зберігались у фундаментальній бібліотеці КДС мали неординарну науково-богословську, освітню і навіть матеріальну цінність.

Про серйозну науково-релігійну вагу фундаментальної бібліотеки КДС свідчить ще такий факт. 30 березня 1868 р. до київського митрополита надійшло відношення від Г. Стремухова. В ньому він просив перевести з Полтавської духовної семінарії в Київську Івана Пічета, вихідця з Герцеговини. Він хотів доповнити і завершити свою працю про історію Сербської Церкви. В цьому допомогти йому повинні були фонди фундаментальної бібліотеки КДС. У Полтавській духовній семінарії І. Пічет працював викладачем церковної історії. Проте в Київській семінарії не було таких вакансій, і тому правлінням було ухвалено рішення перевести його, коли з'явиться нагодаз ${ }^{33}$.

Колишній бібліотекар КДС Харисим Орда в жовтні 1873 р. доповідав правлінню семінарії, що в результаті пожежі у його будинку, яка відбулася 4 вересня 1873 р. були частково розграбовані, а частково згоріли 73 найменування різних книг ${ }^{34}$. Він не міг через це повернути їх семінарії.

\footnotetext{
${ }^{31}$ ЦДІАУ, м. Київ. Ф. 712. Оп. 4: 1913-1914. Спр. 717: Отчеты о состояии семинарии и духовных училищ Киевской епархии. Арк. 22.

${ }^{32}$ ЦДІАУ, м. Київ. Ф. 712. Оп. 3: 1880. Спр. 51: 0 выписке книг и журналов для фундаментальной библиотеки и приобритении для физического кабинета приборов и разных принадлежностей. 84 арк.

${ }_{33}^{33}$ ЦІАУ, м. Київ. Ф. 712. Оп. 3: 1868. Спр. 1: Журналы педагогического собрания. Арк. 53.

${ }^{34}$ ЦДІАУ, м. Київ. Ф. 712. Оп. 3: 1873. Спр. 18: Дъло Педагогическаго Собранія Правления Семинаріи. 0 выпискъ книгъ и журналовъ для фундаментальной библіотеки. Арк. 7-10.
} 
4 грудня 1874 р. бібліотекар КДС Матвій Паторжинський доповідав правлінню семінарії про невпорядкованість літератури в основній фундаментальній бібліотеці. Вона складалася 3 трьох частин: 3 книг, що існували в ній до складання каталогів у 1857 р.; 3 книг, які пожертвував київський митрополит Філарет; з книг, що куплені та пожертвувані після 1857 р. Кожна з цих частин мала свій особливий каталог. Таке роз'єднання викликало труднощі при пошуку однорідних книг і при користуванні ними. На думку М. Паторжинського, доцільніше було б згрупувати їх за мовами: російською, французькою, німецькою, латинською і грецькою. На той час (1874 р.) в каталогах знаходилося 680 карток. 3 огляду на те, що кожен лист паперу коштував 15-25 коп., на новий каталог мало б бути використано бл. 70 руб. На думку бібліотекаря, варто було б створити спеціальну комісію, яка б зайнялася справою впорядкування нового каталогу. Пропозиції М. Паторжинського були схвалені правлінням семінарії. Було створено комісію, до якої увійшли бібліотекар і члени правління П. Ігнатович і Х. Орда ${ }^{35}$.

16 лютого 1875 р. М. Паторжинський повідомляв, що приміщення, в якому знаходилася бібліотека, перебудовувалося. I це дуже заважало справі впорядкування наявних фондів. Бібліотекар вказував, що складання нового об'єднаного каталогу повинно бути відкладено до розстановки книг на нових місцях у перебудованій бібліотеці. Проте, як зазначав М. Паторжинський, для полегшення оформлення систематичного каталогу вже тоді необхідно було почати складання алфавітно-інвентарного переліку книг. Він повинен був приводитися по алфавітному порядку по початковій букві авторів книг (або по початковій букві назви (якщо відсутнє прізвище автора). Повинні були вказуватися: а) кількість томів, б) кількість екземплярів, в) каталог, в якому знаходяться книги і місце в бібліотеці. Крім цього, нові книги, що прибували в бібліотеку, повинні вноситися в інший додатковий каталог по цій же формі. Його запропонували скласти члени комісії, що сформувалася для впорядкування фундаментальної бібліотеки, а саме П. Ігнатович, Х. Орда і М. Паторжинський. У цьому додатковому каталозі вже містилося 712 найменувань у графі «по порядку» ${ }^{36}$.

у 1880 р. бібліотекар Данило Горянський звітував перед правлінням семінарії, що він, закінчивши чорнову корекцію бібліотечних каталогів, почав складати алфавітний i систематичний каталог. Він також зазначав, що ним затрачено вже більше року на створення опису продажної та безплатної («безмъздной») бібліотек. Через це він просив у правління семінарії найняти двох писарів, що дало б йому змогу закінчити заплановані роботи за два місяці. Д. Горянський зазначав, що якщо він виконуватиме ці роботи сам, то це займе не менше року. Він також просив надрукувати бланки, як для алфавітного, так і систематичного каталогів. Це теж значно полегшило б йому роботу ${ }^{37}$.

Бібліотекар Д. Горянський також вважав за потрібне або встановити новий порядок виписки книг, або знайти іншого постачальника («коммисионера»), яким тоді був купець

\footnotetext{
${ }^{35}$ ЦДІАУ, м. Київ. Ф. 712. Оп. 3: 1874. Спр. 35: 0 выписке и покупке книг и журналов для фундаментальной библиотеки семинарии (Отчет о книгах безмездной раздачи ученикам, ведомость о продаже книг). Арк. 83.

${ }^{36}$ ЦДІАУ, м. Київ. Ф. 712. Оп. 3: 1875. Спр. 51: 0 выписке книг и журналов и покупке для фундаментальной библиотеки (отчет о состоянии библиотеки). Арк. 15-16.

${ }^{37}$ ЦДІАУ, м. Київ. Ф. 712. Оп. 3: 1880. Спр. 51: 0 выписке книг и журналов для фундаментальной библиотеки и приобритении для физического кабинета приборов и разньх принадлежностей. Арк. 25.
} 
Оглобин. На думку Д. Горянського, книготорговець перепродає книги семінарії за завищеними цінами. Його ціна була дорожчою на 15 коп. і, між іншим, він ніколи не доставляв одночасно всі книги в семінарію. Цікаво, що цей Оглобин постачав книги і в бібліотеки Київської духовної академії і до університету св. Володимира ${ }^{38}$.

3 доповідної записки від 9 січня 1892 р. бібліотекаря Олександра Клітіна ми дізнаємося, що на той час систематизація каталогу ще не була завершеною. Бібліотекар доповідав, що вже покійний протоієрей Старокиївської Георгіївської церкви М. Паторжинський заповідав пожертвувати свої книги для бібліотеки КДС. Всього від нього надійшло 348 назв книг (348 екземплярів і 612 томів). 3 них до фундаментальної бібліотеки було включено 22 назви книг (22 екземпляри і 34 томи) ${ }^{39}$. Крім того, у цьому році, за заповітом митрополита Платона, на фундаментальну бібліотеку було виділено «капітал в 2000 руб.». Ще він заповідав направити в КДС книги. Але це мало бути не більше 1/15 від загального обсягу його приватної бібліотеки. Наприкінці 1892 р. О. Клітін повідомляв, що відповідно до заповіту митрополита Платона, КДС отримала 1200 томів книг. Через відсутність спеціальної шафи, всі вони складені на підлозі бібліотеки. Бібліотекар просив закупити шафи для книг, оскільки вся література, що надходили до бібліотеки, не поміщалася у старих шафах ${ }^{40}$.

Інший бібліотекар Григорій Звєрєв 25 вересня 1893 р. повідомляв, що ректор подарував бібліотеці КДС 30 назв книг (в 49 томах). Також сумський єпископ Петро подарував у фундаментальну бібліотеку 36 назв книг (в 87 томах) $)^{41}$.

В одному з каталогів фундаментальної бібліотеки (початку XX ст.) був перерахований список з 2583 екземплярів рукописних і друкованих книг. Він вміщував у собі перелік книг латиною (872 екз.), російською (872 екз.), французькою (317 екз.), німецькою (98 екз.), маловідомими мовами (122 екз.). Також тут вказувалося, що у бібліотеці було 262 екземпляри книг, що належали до духовної освіти, 40 рукописних книг, 101 географічний та історичний посібник, 3 фізичні речі, 44 медалі і монети, 22 картини ${ }^{42}$. I це - лише один каталог. Їхнє впорядкування дійсно займало багато енергії, часу та приватних коштів бібліотекарів.

Очевидно, справа впорядкування фундаментальної бібліотеки була завершена 3 перенесенням її у нові приміщення, що на горі Кудрявець. Але про це можемо лише здогадуватись.

Важливу роль, як частина основної бібліотеки, відігравала так звана «продажна бібліотека». Сюди входили або старі книги, або ті, які вийшли з ужитку. Вони продавалися учням з метою отримання додаткових фінансових надходжень у семінарію.

Так, у 1872 р., від продажу книг своєкоштним учням було отримано 153 руб. 22 коп. ${ }^{43}$

\footnotetext{
${ }^{38}$ Ibid. Арк. 28, 73.

${ }^{39}$ ЦДІАУ, м. Київ. Ф. 712. Оп. 3: 1892. Спр. 22: 0 поступивших книгах. О книгах из библиотек митропол. Платона и Паторжинского. Арк. 74.

${ }^{40}$ ЦДІАУ, м. Київ. Ф. 712. Оп. 3: 1893. Спр. 8: 0 поступлении и выписке книг в фундаментальную и ученическую библиотеку. Арк. 7.

${ }^{41}$ Ibid. Арк. 10, 12, 15, 16.

${ }^{42}$ ЦДІАУ, м. Київ. Ф. 712. Оп. 4: б. р. Спр. 946: Каталог книг библиотеки Киевской семинарии (без года). Арк. 208-209.

${ }^{43}$ ЦДІАУ, м. Київ. Ф. 712. Оп. 3: 1873. Спр. 18: 0 выпискњ книг и журналов для фундаментальной библіотеки. Арк. 6.
} 
У звіті про стан продажної бібліотеки за 1884 р. вказувалося, що за увесь поточний рік учнями було куплено лише 13 книг на суму 6 руб. 30 коп. Бібліотекар Микола Клітин вказував, що наприкінці року залишилось 646 екземплярів книг, орієнтовна вартість яких 508 руб. 58 коп. Він також зазначав, що 206 книг, що по-суті були навчальними підручниками та посібниками, вийшли з ужитку. Інші книги продавалися по ціні, дещо дорожчою за крамничну. Це, вважав М. Клітин, головні причини того, що книги так погано продавалися. Бібліотекар пропонував ліквідувати продажну бібліотеку, а всі ї̈ книги перевести до учнівської бібліотеки ${ }^{44}$. Цікаво, що у 1885 р. 3 цієї бібліотеки було продано лише 2 книги, I і II випуск «Церковної історії» Смирнова, на суму 3 руб. 80 коп. ${ }^{45}$

Господарське управління при Св. Синоді здійснювало повний контроль за надходженням та обігом підручників у духовних семінаріях. Але такі обмеження сприймалися керівництвом КДС абсолютно нормально. На одному з засідань педагогічних зборів 1868 р. наголошувалося, що книги, які не пройшли цензуру і «в основі яких лежить грубий матеріалізм і не лише безвір'я, а й заперечення духовної природи людини», не повинні використовуватися при навчанні учнів у КДС. Наприклад, таким екземпляром були «Основи науки антропо-етнології або закони відносин між людиною і природою» Октавія Мільчевського («Основанія науки Антропо-этнологіи или законы отношеній между человекомъ и природою») ${ }^{46}$. У 1891 р. обер-прокурор Св. Синоду К. Победоносцев прислав київському митрополиту Платону невелике видання «Беседы о томъ, что лжеученіе графа Л. Толстого разрушаеть саміе основы не только православной христианской вђры, но и всякой религіи». Цікаво, що поряд 3 ним митрополит отримав й інші брошурки на релігійну тематику: «Бросте курить», «Какой вредъ приноситъ человЂку табак», «БЪседы о пьянствђ ${ }^{47}$.

Відразу після створення учнівської бібліотеки до правління семінарії надійшли накази Св. Синоду, які суворо контролювали вміст літератури в них. Щоб запобігти обігу «шкідливих книг» між учнями, книги в учнівських бібліотеках повинні були виписуватися не інакше, як за рекомендаціями викладачів, кожним по своїй галузі і з затвердженням педагогічних зборів ${ }^{48}$.

Учням семінарії доволі часто роздавали книги, як нагороду за успішність. Але вартість таких подарунків була невисокою. Зазвичай, вони коштували від 10 коп. до 2 руб. ${ }^{49}$ Наприклад, за нашими підрахунками, у 1872 р. казеннокоштним учням було безкоштовно роздано 687 екземплярів книг. При цьому, це відбувалося поступово протягом всього навчального року і, зазвичай, у кількості до 20 книг (а в окремих випадках - до 40) ${ }^{50}$.

\footnotetext{
${ }^{44}$ ЦДІАУ, м. Київ. Ф. 712. Оп. 3: 1884. Спр. 26: О поступлении книг в фундаментальную библиотеку семинарии и с отчетом по этому этому предмету за 1884 г. Арк. 57.

${ }^{45}$ ЦДІАУ, м. Київ. Ф. 712. Оп. 3: 1885. Спр. 14: О состоянии библиотеки фундаментальной и ученической, физического кабинета и о поступлении книг в библиотеку. Арк. 40.

${ }^{46}$ ЦДІАУ, м. Київ. Ф. 712. Оп. 3: 1868. Спр. 1: Журналы педагогического собрания. Арк. 118.

${ }^{47}$ ЦДІАУ, м. Київ. Ф. 712. Оп. 3: 1891. Спр. 25: 0 выписке книг в фундаментальную и ученическую библиотеку. Арк. 10.

${ }^{48}$ ЦДІАУ, м. Київ. Ф. 712. Оп. 3: 1868. Спр. 1: Журналы педагогического собрания. Арк. 122-123; Спр. 14: Указы и циркуляры Св. Синода а такъ же и копіи съ нихъ. Арк. 57, 61.

${ }^{49}$ ЦДІАУ, м. Київ. Ф. 712. Оп. 3: 1868. Спр. 100: Дьло о выписке книгъ потребных для безмездной раздачи и продажи ученикамъ Семинаріи и подвьдомых ей училищъ. 59 арк.

${ }^{50}$ ЦДІАУ, м. Київ. Ф. 712. Оп. 3: 1873. Спр. 18: 0 выпискъ книг и журналов для фундаментальной библіотеки. Арк. 7-10.
} 
Часто Св. Синод направляв для роздачі казеннокоштним учням Біблію, або її частини. У 1886 р. Господарське Управління при Св. Синоді надіслало учням КДС 110 екземплярів Нового Заповіту. Від правління семінарії вимагалися щорічні звіти про роздачу книг казеннокоштним учням ${ }^{51}$. У своєму звіті керівництво семінарії вказувало, що навіть у сукупності з надходженнями цих книг за 1882 р., все-одно не вистачає ще 20 екземплярів для казеннокоштних. 18 листопада 1891 р. з Господарського управління в КДС надіслано 98 екземплярів Біблії, «для безкоштовної роздачі тим учням, що вступили до КДС у 1891 р.» . $^{2} 29$ жовтня 1892 р. з Господарського Управління Св. Синоду в КДС було надіслано для безплатної роздачі учням 110 екземплярів Біблії ${ }^{53}$

31884 р. до фундаментальної бібліотеки знову надходять звіти про стан бібліотек 3 духовних училищ Київської єпархії, що перестали сюди посилатися ще на поч. 1870-х рр. Це яскраво видно з більшості тогочасних бібліотечних звітних документів.

Коли в лютому 1868 р. з Києво-Софіївського духовного училища в КДС прибув реєстр книг, які планувалося використати у продажній бібліотеці, то правління семінарії вимагало інформацію про: 1) імена видавців чи авторів книг, 2) роки видання, 3) які з цих книг рекомендовані як підручники Св. Синодом. Це, перш за все, стосувалося тих видань, про яких така інформація була відсутньою. До наступного засідання педагогічних зборів ці вимоги були виконані та правління семінарії дозволило правлінню училища клопотатися перед Св. Синодом про виписку зазначених книг з його складів ${ }^{54}$.

Нагляд семінарій за діяльністю бібліотек духовних училищ був достатньо серйозним. У 1890-х рр. залишалося чинним «Положення минулої комісії духовних училищ» («Положенія бывшей комиссіи духовных училищъ») від 1825 р. про встановлення таких термінів і положення для використання навчальної літератури. Слов'янська і російська граматика була розрахована на два роки, інші книги - на п'ять років. Книги вартістю до 50 коп. потрібно було видавати по одному екземпляру лише на одного учня; книги вартістю до 1 руб. - на двох учнів; а ті, які вищі 1 руб. - на 3 учнів. Географічні атласи та лексикони видавалися по одному екземпляру на 10 осіб, географічні карти і глобуси видавалися по одному на навчальний заклад 55 . Навіть після такого часового проміжку правління семінарії ставилося до цих положень не менш серйозно, ніж в рік їхнього затвердження. На наш погляд це є прямим доказом того, що проблеми забезпечення духовних училищ літературою, подібно як і в першій чверті XIX ст., залишалися повністю невирішеними навіть наприкінці 1800-х рр.

Висновки. Отже, фундаментальна бібліотека відігравала важливу та неординарну роль у навчальному процесі КДС. Література книгосховища була вагомою складовою навчальної інфраструктури.

\footnotetext{
${ }^{51}$ ЦДІАУ, м. Київ. Ф. 712. Оп. 3: 1886. Спр. 17: 0 выписке книг в фундаментальную и ученическую библиотеку за 1886 г. Арк. 31, 58.

${ }^{52}$ ЦДІАУ, м. Київ. Ф. 712. Оп. 3: 1891. Спр. 25: 0 выписке книг в фундаментальную и ученическую библиотеку. Арк. 9.

${ }^{53}$ ЦДІАУ, м. Київ. Ф. 712. Оп. 3: 1892. Спр. 22: 0 поступивших книгах. 0 книгах из библиотек митропол. Платона и Паторжинского. Арк. 72.

${ }^{54}$ ЦДІАУ, м. Київ. Ф. 712. Оп. 3: 1868. Спр. 1: Журналы педагогического собрания. Арк. 19, 23-24.

${ }^{55}$ ЦДІАУ, м. Київ. Ф. 712. Оп. 3: 1893. Спр. 8: О поступлении и выписке книг в фундаментальную и ученическую библиотеку. Арк. 3.
} 
У 1868 р. в КДС були складені правила та порядок збереження і видачі книг з фундаментальної бібліотеки. Документ складався з трьох частин. Перша стосувалася прийому книг у книгосховище та їх зберігання. Друга - регулювала порядок використання учнями фондів бібліотеки. Третя частина мала на меті зберегти книги від псування й окреслювала норми відповідальності, яку понесуть учні у разі пошкодження літератури.

Кошти, на які поповнювалася й утримувалася фундаментальна бібліотека вносилися окремим пунктом у щорічний семінарський кошторис у § Господарські витрати. У 18671871 рр. на неї виділялося по 137 руб. на рік. До середини 1880-х рр. ця сума коливалася в межах 400-500 руб. на рік. Таке надмірне фінансування бібліотеки, очевидно, було пов'язане з активним наповненням фізичного кабінету і учнівської бібліотеки, витрати на які обраховувалися однією спільною статтею кошторису. 3 другої половини 1880-х рр. на бібліотеку виділялося рівно 325 руб. на рік. I в подальшому ця сума такою й залишалася.

Книги до бібліотеки купувалися в книготорговців м. Києва, але траплялися й випадки, коли їх закуповували і в інших містах Російської імперії, найчастіше - в Москві і Петербурзі. Як правило, звичайні не раритетні видання коштували від 2 до 5 руб.

У другій половині XIX ст. в книгосховища семінарії щорічно закуповували від 100 до 250 екземплярів літератури. Кількість придбаних книг з року в рік дуже коливалася.

Протягом 1870-х-1880-х рр. у фундаментальній бібліотеці знаходилося більше 6 тис. книг у 12 тис. томах. До початку Першої світової війни їхня кількість подвоїлася майже 12 тис. книг у 20 тис. томах.

Література, якою була наповнена фундаментальна бібліотека, мала неординарну науково-релігійну цінність. У ній підручники й учнівські посібники становили меншість - від 1/3 в середині XIX ст. до початку XX ст. Це є першою ознакою глибоко наукового, не педагогічного характеру фундаментальної бібліотеки. Другою - $є$ те, що співвідношення російськомовної літератури до іншомовної - 3:2, при чому 60-70\% книг іноземними мовами були написані стародавніми мовами - грецькою, латиною, івритом.

Якщо у середині XIX ст. фундаментальна бібліотека лишалася абсолютно невпорядкованою, то у 1857 р. були складені перші каталоги. У середині 1870-х рр. питання про нове впорядкування бібліотеки порушилося знову. Проте цей процес затягнувся на 30 років і тривав до кінця XIX ст. В упорядкуванні фундаментальної бібліотеки активну участь брали такі члени семінарського правління та бібліотекарі: М. Паторжинський, П. Ігнатович, Х. Орда, Д. Горянський, О. Клітін, Г. Звєрєв. На цю роботу витрачалося багато енергії, часу і приватних коштів бібліотекарів.

У 1870-1880-х рр. при основній бібліотеці були так звані «продажна» та «безплатна» бібліотеки. Кількість книг у них була невеликою. Література з першої продавалася учням, а з другої - роздавалася безкоштовно.

Книгосховища семінарії й обіг книг піддавалися серйозній цензурі й обмеженням. Господарське управління при Св. Синоді здійснювало суворий нагляд за надходженням і вибуттям літератури з духовних навчальних закладів. Правління семінарії щорічно звітувало про всі свої бібліотечні придбання та покупки.

За успішність учнів нагороджували книгами. Для безкоштовних роздач казеннокоштним учням з відомств Св. Синоду часто надсилалися Біблії або частини Св. Писання. 


\title{
Functioning of Fundamental Library of Kyiv Theological Seminary in the Second Half of the $19^{\text {th }}$ - the Beginning of the $20^{\text {th }}$ Century
}

\begin{abstract}
An important component of the history of Kyiv Theological Seminary, the functioning of its main ('fundamental') library is studied. The rules and procedure for depositing and checking out books from it and the content of each of the three parts of these rules are studied.

It is stated that the important part of the collections of the fundamental library (in the middle of the $19^{\text {th }}$ century) was scientific literature. It is found out that despite the scientific nature, the collections of the book repository were an important part of the educational infrastructure. It is revealed that in 1867-1871 the budget of the repository was 137 rubles per year. Till the mid-1880s, the sum ranged from 400 to 500 rubles per year, and from the second half of the 1880s, the budget was exactly 325 rubles per year. And from that time on, the sum remained unchanged.

The peculiarities of organizing library funds in the last quarter of the $19^{\text {th }}$ century are characterized. It is proved that it was a laborious and costly process. The changes and increasing diversity in the library's acquisitions during the second half of the $19^{\text {th }}$ - the beginning of the $20^{\text {th }}$ century are analyzed in detail. The names of the librarians and members of the seminary board who took an active part in organizing the fundamental library are mentioned.

It is noted that if in the 1880s in the library there were 6,000 books in 12,000 volumes, then before the First World War there were already almost 12,000 books in 20,000 volumes, that is, the quantitative composition of the fundamental library for thirty years was doubled.

Attention is drawn to the serious censorship and restriction of book circulation by the departments of the Holy Synod. The peculiarities of purchasing the items for the library are shown. It is determined that the items for the library were bought from booksellers in Kyiv. As a rule, ordinary non-rare items cost from 2 to 5 rubles.

It is proved that students were awarded books for their academic achievements. It is found out that even after the adoption of the new statute of theological seminaries and religious schools, the libraries of religious schools were subordinated to the fundamental library of Kyiv Theological Seminary.
\end{abstract}

Keywords: Orthodox Church, secondary theological education, theological seminaries, Kyiv Theological Seminary, library, book repository, literature 